\title{
TÜRK YÜKSEKÖĞRETIMINDE SURIYELi MüLTECILER
}

\section{DERLEME MAKALESI}

\section{Haluk GÜNGÖR' ${ }^{1}$, Taşkın SOYSAL ${ }^{2}$}

1 Öğr. Gör. Dr., Gazi Üniversitesi TÖMER, halukgungor1@gmail.com, ORCID: 0000-0002-4111-4106.

2 Dr. Öğr. Üyesi, Karamanoğlu Mehmetbey Üniversitesi, Eğitim Fakültesi, Türkçe Eğitimi Bölümü, taskinsoysal@gmail.com, ORCID: 0000-0003-2753-5905.

Geliş Tarihi: $30.06 .2021 \quad$ Kabul Tarihi: $28.10 .2021 \quad$ DOI: 10.37669 milliegitim.960083

Öz: İnsanlığın başlangıcından bu yana dünya tarihine yön veren büyük küçük tüm savaşların sosyal ve toplumsal alanlarda çok büyük etkileri olmuştur. İnsanlar, savaşlar nedeniyle yaşadıkları toprakları gerek kalıcı gerekse de geçici olarak terk edip yeni bölgelere, yeni ülkelere yerleşmek durumunda kalmışlardır. Bu durum hem göç edenler hem de göç edenlerin yaşadıkları topraklardaki yerli halklar için birtakım yeni ihtiyaçların doğmasına yol açmıştır. Suriye iç savaşıyla birlikte ortaya çıan göçmen krizinden Türkiye de doğrudan etkilenmiş, 2021 yılı itibarıly Türkiye'de yaşayan Suriyeli göçmen sayısı üç buçuk milyonu geçmiştir. Türkiye, iç savaş sebebiyle Suriyeli göçmenlerin gelmeye başladıkları andan itibaren her alanda çeşitli tedbirler almaya başlamıştır. Bu tedbirlerin ilk ve en önemlilerinden biri Suriyeli mültecilerin eğitime katılımlarıdır. İç savaş sebebiyle göçmenlerin kesintiye uğrayan eğitim yaşamlarının Türkiye'de en verimli şekilde devam etmesi için gerekli çalışmalar yapılmış, ilköğretimden yükseköğretime kadar tüm seviyelerde Suriyeli göçmenlerin eğitime katılımları sağlanmıştır. Bu çalışma, Türk yükseköğretiminde Suriyeli mültecilerin durumlarının ele alındığ1 bir derleme çalışmasıdır. Çalışmada öncelikle yükseköğretimde Suriyeli mültecilerin durumların ele alan kaynaklarla ilgili kapsamlı bir alanyazın taraması gerçekleştirilmiştir. Bu bağlamda göç, eğitim ve göç, Suriyeli mültecilerin topluma kazandırılması, yükseköğretim çağındaki ve diğer öğretim kademesindeki Suriyelilerin durumları, yaşadıkları sorunlar ve çözüm önerilerine yönelik yapılmış ulusal ve uluslararası çalışmalar incelenmiştir. Yapılan incelemede her bir çalışmada elde edilen bulgular üzerinde durularak Türk yükseköğretiminde Suriyeli mültecilerin durumları üzerine bir senteze gidilmiştir. Eğitim çağındaki Suriyeli mültecilerin, okul öncesinden yükseköğretime kadar okullaşmaları ve başarılı olmaları yaşanan birçok sorunun da çözümünü sağlayacaktır. Özellikle üniversite çağındaki genç nüfusun nitelikli bireyler olarak yetişmeleri, kendi açılarından faydalı olacağı gibi Türk toplumunun mültecilere bakış açısının olumlu anlamda değişmesini de beraberinde getirecektir.

Anahtar Kelimeler: Göç, göçmen, Suriyeli mülteciler, Türk yükseköğretiminde Suriyeliler 


\title{
SYRIAN REFUGEES IN TURKISH HIGHER EDUCATION
}

\begin{abstract}
:
All the wars, big and small, that have shaped world history since the beginning of humanity, have had great effects on social and societal fields. Due to wars, people had to leave their lands permanently or temporarily and settle in new regions and new countries. This situation has led to the emergence of some new needs for both the immigrants and the indigenous peoples in the lands where the immigrants live. Turkey was also directly affected by the migrant crisis that emerged with the Syrian civil war, and as of 2021, the number of Syrian immigrants living in Turkey exceeded three and a half million. Turkey has started to take various measures in every field since the Syrian immigrants started to arrive due to the civil war. One of the first and most important of these measures is the participation of Syrian refugees in education. Necessary studies were carried out to ensure that the education life of immigrants, which was interrupted due to the civil war, continues in the most efficient way in Turkey, and Syrian immigrants at all levels from primary education to higher education were provided with education. This study is a compilation study that deals with the situation of Syrian refugees in Turkish higher education. In the study, first of all, a comprehensive literature review was carried out on the sources dealing with the situation of Syrian refugees in higher education. In this context, national and international studies on migration, education and migration, reintegration of Syrian refugees into society, the situation of Syrians at the age of higher education and at other education levels, the problems they experience and solution proposals have been examined. In the study, a synthesis was made on the situation of Syrian refugees in Turkish higher education by emphasizing the findings obtained in each study. The schooling and success of the Syrian refugees in the education age, from pre-school to higher education, will also provide solutions to many problems. The fact that especially the young population of university age will be raised as qualified individuals will be beneficial from their own perspective and will also bring about a positive change in the perspective of the Turkish society towards refugees.
\end{abstract}

Keywords: Migration, immigrants, Syrian refugees, Syrians in Turkish higher education 


\section{Giriş}

Birinci Dünya Savaşı'ndan sonra kurulan yeni dünya düzeninde, Batılı ülkeler Afrika ve Kuzey Afrika'daki birçok Arap devletini kendi sömürgesi hâline getirirken yerel halk kendi ülkesinin zenginliklerinden yeterince kazanç sağlayamamaktadır. Ayrıca bu ülkeler gelir dağılımında da ciddi sorunlar yaşamaktadırlar. Demokrasi değil, diktatörlüğün hâkim olduğu bu ülkelerde işsizlik, kötü yaşam koşulları, insan haklar1nın olmayışı, eğitim-öğretim hakkından yararlanamama gibi nedenlerden dolayı, 2010 yılının Aralık ayında Tunus'ta bir gencin kendini yakmasıyla bütün Arap ülkelerini etkisi altına alacak bir olayın fitili ateşlenmiştir.

"Arap Baharının ilk halkasını oluşturan Tunus, kısa ancak kanlı bir geçişe sahne olmuştur. 'Yasemin Devrimi' adı verilen bu geçiş, yerleşik iktidarın muhalefete geçişi ile sona ermiştir. Bu olaylar, ekonomik sebeplerle patlak verse de demokrasi ve insan hakları taleplerini beraberinde getirmiştir" (Akar Yüksel ve Bingöl, 2013: 310). İlk bakişta Tunus'ta yaşanan ve sadece Tunus'u ilgilendirebilecek bir olay, sonraki günlerde Kuzey Afrika ve Orta Doğu'da bulunan Arap ülkelerine de (Cezayir, Lübnan, Ürdün, Moritanya, Sudan, Umman, Yemen, Suudi Arabistan, Mısır, Suriye, Cibuti, Fas, Irak, Bahreyn, İran, Libya, Kuveyt, Batı Sahra) sıçramıştır. Adı geçen ülkelerin bazılarında küçük çaplı olaylar yaşanırken önemli bir bölümünde ise olaylar neticesinde yönetimler el değiştirmiş; halkın başarılı olamadığı durumlarda dikta yönetimlerle halk arasındaki mücadele bir iç savaşa dönüşmüştür. Bu savaşın en yıkıcı, yoğun ve en uzun süre devam edeni Suriye iç savaşıdır. (Tuygan, 2011; Akar Yüksel ve Bingöl, 2013; Nebati, 2019; Sayın, 2019; Ansarian, 2020; Y1lmaz, 2020)

"Arap Baharı"nın etkisiyle diktatörleri devrilen bazı ülkelerden ilham alan Suriyeli muhalifler, Beşşar Esad'a karşı demokratik bir yönetim talebini dile getirmişlerdir. Ancak bu talep, Esad tarafından dikkate alınmayıp tam tersine muhalif hareketi ortadan kaldırmaya yönelik bir katliama evrilmiştir. Başta Türkiye olmak üzere Birleşmiş Milletler, uluslararası oluşumlar ve birçok ülkeden yapılan "barış" ve "demokrasi" çağrıları sonuçsuz kalmıştır. Böylece olaylar, Suriye rejimi ile halk arasında bir iç savaşa dönüşmüştür. Bu iç savaş sırasında yüz binlerce insan hayatını kaybetmiş ve milyonlarca insan vatanını terk etmek zorunda kalmıştır.

Suriye'deki olaylar, zaman geçtikçe önü alınamayan bir iç savaşa dönüşerek belki de "Arap Baharı"nı yaşayan ülkeler arasında en kanlı örneği teşkil etmiştir. Uzayan bu süreç, ülkeyi dış müdahalelere açık ve hatta mecbur hâle getirmiştir. Özellikle Suriye'nin kuzeyinde kaybolan devlet otoritesi bazı terör örgütlerinin kendilerine alan bulmalarına neden olmuştur. Rejimin zulmüne maruz kalan bölge halkı, bu acımasız terör örgütleriyle de mücadele etmek zorunda kalmıştır. Bu durum, uluslararası müdahaleyi kaçınılmaz kılarak özellikle Suriye ile en uzun kara sınırına sahip ülke olan Türkiye'nin askerî müdahalesini zorunlu hâle getirmiştir. Bütün bu olaylar yaşanırken barışın tesis edilmesine yönelik yapılan toplantılar sonuçsuz kalmıştır. Devletlerin böl- 
gedeki çıkarlarının da çatışması, Suriye iç savaşının uzamasının başka bir nedenidir. Bütün bu olayların en ağır faturasını yine Suriye halkı psikolojik, ekonomik, eğitim ve hatta yaşam haklarının elinden alınmasıyla en ağır biçimde ödemiştir.

Yaklaşık on yıldır süregelen Suriye iç savaşında, Birleşmiş Milletler Mülteciler Yüksek Komiserliğinin son verilerine göre, Suriye içerisinde yardım ihtiyacı olan kişi sayısı 13,1 milyon; Suriye içinde yerinden edilmiş kişi sayısı 6,6 milyon; ulaşması zor ya da kuşatılmış yerlerde hayatını sürdüren kişi sayısı 2,98 milyona ulaşmış durumdadır (UNHCR, 2018). Bunun yanı sıra, 6 Ocak 2021 itibarıyla güncellenen verilere göre, ülke dışına göç etmek zorunda kalan kayıtlı Suriyeli sayısı 5.588.753'tür. Bu insanların 3.643.769'unu Türkiye tek başına barındırmaktadır. Türkiye'den başka Lübnan, Ürdün, Irak ve Mısır; Suriyeli mültecilere ev sahipliği yapmaktadır. Bununla ilgili güncel veriler Tablo 1'de verilmiştir.

Tablo 1. Suriyeli Mültecilerin Ülkelere Göre Dağılımı

\begin{tabular}{lccc}
\hline Ülke & $\begin{array}{c}\text { Güncelleme } \\
\text { Tarihi }\end{array}$ & Yüzde & Nüfus \\
\hline Türkiye & 06.01 .2021 & $\% 65,2$ & 3.643 .769 \\
\hline Lübnan & 30.09 .2020 & $\% 15,7$ & 879.529 \\
\hline Ürdün & 04.11 .2020 & $\% 11,8$ & 661.997 \\
\hline Irak & 30.11 .2020 & $\% 4,3$ & 241.682 \\
\hline Misır & 31.10 .2020 & $\% 2,3$ & 130.187 \\
\hline Diğer (Kuzey Afrika) & 31.01 .2020 & $\% 0,6$ & 31.657 \\
\hline
\end{tabular}

Kaynak: http://data2.unhcr.org/en/situations/syria, 2021.

Tablo 1 incelendiğinde, Türkiye'nin Suriyeli mültecilere 06 Ocak 2021 tarihi itibaryyla ev sahipliğinde lider ülke olduğu görülmektedir. Suriyeli mültecilerin \%65,2'sini Türkiye tek başına ağırlamaktadır. Savaştan kaçan Suriyelilerin \%15,7'si Lübnan'a; \%11,8'i Ürdün'e; \%4,3'ü Irak'a ve \%2,3'ü Mısır'a sı̆̆ınmıştır. \%0,6'l1k az bir kesim ise Kuzey Afrika ülkelerinde yaşamaktadır.

Coğrafi yakınlık, kültürel benzerlik gibi ögeler, savaştan kaçan Suriyelilerin büyük bir çoğunluğunun $(\% 65,2)$ Türkiye'ye sığınmalarının belki de en önemli nedenlerinden biridir. Tarih boyunca Anadolu coğrafyası Avrupa kıtasına ulaşmak için önemli bir geçiş güzergâhı olmuştur. Suriyeli sığınmacıların Türkiye'yi, Avrupa ülkelerine ulaşmak için transfer bir ülke olarak görmeleri de Türkiye'deki sığınmacı sayısını artıran önemli bir etkendir. Ancak Avrupa ülkelerinin bu yükü paylaşmak istememeleri, mültecileri Akdeniz üzerinden tekneler veya şişme botları kullanarak kaçak yollarla Avrupa'ya geçmeye itmektedir. Bu geçişler sırasında ise birçok insan boğularak haya- 
tını kaybetmiştir. Ne yazık ki uluslararası kamuoyunun sessizliği, bu tür olayların artmasına neden olmaktadır (Efe, Pandır ve Paksoy, 2018). 2 Eylül 2015 tarihinde cesedi Bodrum kıyılarına vuran "Aylan Bebek" bu olayların bir simgesidir.

Suriye iç savaşından dolayı beklenmedik bir yoğunlukta göç dalgasına maruz kalan Türkiye, birçok sorunla da baş etmek zorunda kalmaktadır. Suriyeli mültecilerin barınma ihtiyaçları sağlandıktan sonra, bu insanların kültürel uyumlarının sağlanması ve her kademede eğitim hayatlarından geri kalmamaları için acil önlemlerin alınması gerekmektedir. Bu kapsamda bu çalışmada, Suriyeli mültecilerin Türkiye'de eğitim açısından yaşadıkları sorunlar; yükseköğretim kurumlarındaki Suriyeli mülteci öğrencilerin karşılaştıkları problemler bağlamında ele alınmaktadır. Dil sorunları ve hedef kültüre uyum gibi değişkenler analiz edilerek sorunun çözümüne yönelik öneriler geliştirilmiştir.

\section{Yöntem}

Çalışma, konuyla ilgili alanyazının taranmasıyla hazırlanan bir derleme makalesidir. Derleme çalışmaları, bir araştırma problemine odaklanmak yerine belirli bir konuyu alanyazın bağlamında inceleyen çalışmalardır (Aydoğdu, Karamustafaoğlu ve Bülbül, 2017). Bu araştırma yönteminde, bir konu hakkında birden çok araştırmanın bulguları bir araya getirilerek, bunların eleştirel bir analizi yapılır (Karaçam, 2013). Çalışmada göç, eğitim ve göç, Suriyeli mültecilerin topluma kazandırılması, yükseköğretim çağındaki ve diğer öğretim kademesindeki Suriyelilerin durumları, yaşadıkları sorunlar ve çözüm önerilerine yönelik yapılmış ulusal ve uluslararası çalışmalar incelenmiştir. Yapılan analizler sonucunda var olan durum ayrıntılı bir şekilde betimlenerek çözüm önerileri geliştirilmiştir.

\section{Eğitim ve Göç}

“Göçler sosyo-ekonomik sebeplerle olabileceği gibi aynı zamanda sosyo-politik nedenlerden dolayı da gerçekleşebilmektedir. Göç hareketleri ülke içi veya uluslararası sınırları aşarak herhangi bir nedenle gerçekleşen bir nüfus hareketidir" (Harunoğulları, Süzülüş ve Polat, 2019). Dünya genelinde çeşitli nedenlerden dolayı ülkelerinden göç eden insan sayısı her geçen yıl artmaktadır. Bu göçler kimi zaman bireylerin daha iyi bir hayat yaşama arzusu ile gönüllü göç iken kimi zaman da zorunlu göç olma özelliği taşımaktadır. Zorunlu göçler, bireylerin göç kararlarını kendi istekleriyle al(a) madıkları savaş, siyasal baskılar, doğal afetler gibi engellenemeyen olaylar karşısında yapılan göçlerin tamamı, bu kategoride değerlendirilir (Battır, 2020). Sı̆̆ıımacı ya da mülteci gibi nitelendirmelere ilişkin sorunlar, zorunlu göçün getirdiği kavram kargaşalarından biridir. 20. yüzyılın başlarında çok uluslu imparatorlukların dağılmaya başlaması, insanlık tarihi kadar eski olan yerinden edilmeyi, mültecilik kavramı bağlamında tartışılmasını sağlamıştır (Soguk,1999). Göçe zorlanan insanların yasal statüleri kadar sığındıkları ülkelerdeki sosyal statüleri de ilk karşılaşılan sorunların başında gelmektedir. Ancak nedeni ve türü ne olursa olsun, zorunlu olarak göç eden bireylere hangi 
tanımlama yapılırsa yapılsın, bireylerin doğup büyüdükleri ülkelerden yakın kültür olarak algılanan başka bir ülkeye tamamen yerleşmeleri bile birçok zorluğu beraberinde getirmektedir. Zorunlu göçe itilen Suriye halkının yaklaşık 10 yıldır yaşadıkları; bunun en iyi, en güncel ve mültecilik bağlamında çözülmesi gereken acil bir durum örneğidir.

İkinci Dünya Savaşı sonrasında evlerinden kaçan, kaçmaya zorlanan ya da evlerini kaybeden milyonlarca Avrupalı mülteciye yardım etmek amacıyla 1950 yılında kurulan Birleşmiş Milletler Mülteciler Yüksek Komiserliği (BMMYK), 3 yıllık bir görev süresi ön görülerek kurulmuştur. Başlangıçta İkinci Dünya Savaşı'nın yarattığ1 toplumsal sorunların çözümü için 3 yıllık bir sürenin yeteceği ön görülmüştür ancak Birleşmiş Milletler çatısı altında kurulan bu kurum, dünya genelinde artan mülteci krizlerinde günümüzde de yardım sağlayan kurumlardan biridir. BMMYK'nin verdiği güncel sayılara göre, 2019 yılı itibarıyla 79,5 milyondan fazla insan yerinden edilmiş, 26 milyon mülteci, 45,7 milyon kendi ülkeleri içinde yerinden edilmiş insan ve 4,2 milyon sığınmacı bulunmaktadır (UNCHR, 2018). BMMYK'nin "Coming Together For Refugee Education. Education Report 2020" adlı raporunda, dünya genelinde eğitim çağındaki mülteci çocukların ilkokula kayıt oranı \%77'dir. Ortaokula katılım oranı \%31 iken yükseköğretime katılım oranı ise yalnızca \%3'tür. 12 ülkenin (Çad, Etiyopya, Irak, Ürdün, Kenya, Lübnan, Pakistan, Ruanda, Güney Sudan, Tanzanya, Türkiye, Uganda) örneklem olarak alındığı bu raporda 1,8 milyon çocuk okul dışındadır (UNCHR, 2018).

Göç gerçeği, mültecilerin gittikleri ülkelere her anlamda uyum sağlamalarını gerektirmektedir. Bu alanlardan biri de kuşkusuz eğitim olmaktadır. Mültecilerin toplumsal hayata katılmasının en önemli basamaklarından biri eğitim-öğretim ortamlarıdır. "2014-2015 eğitim öğretim döneminde Türk idaresindeki 25 kampta yaşayan okul çağındaki çocukların \%90'ı okula kayıt yaptırmışsa da kamplardaki çocuk sayısı, okul çağındaki Suriyeli çocuk nüfusun sadece \%13'ünü teşkil etmektedir. Kamp dişında yaşayan Suriyeli mültecilerin ise eğitim durumları son derece kötü durumdadır. Burada Türkiye, devreye girerek çocuklarının eğitimi için geçici eğitim merkezlerine olur vererek çocukların devlet okullarında eğitim alması için gerekli adımların önünü açmıştır" (Öztürk ve Çoltu, 2018). "Türkiye sığınma ve mülteci hareketleri yönünden oldukça tecrübeli bir ülke konumundadır. Nitekim sınır komşularında ve yakın çevresinde çeşitli nedenlere bağlı olarak ortaya çıkan göç hareketlerinden çok defa birebir etkilenmiş ve bu sürecin içerisinde yer almak durumunda kalmıştır" (Paksoy, 2017). Aynı tecrübe Suriyeli mültecilerin eğitime katılımında da yol gösterici olmuştur ancak Suriyeli mültecilerin eğitime katılımları devlet eliyle kolaylaştırılmış olsa da eğitime katılımda etkili olan birçok farklı etkenin varlığı söz konusudur.

\section{Eğitim ve Toplumsal Uyum}

Birleşmiş Milletler çatısı altında faaliyet gösteren "Uluslararası Göç Örgütü"nün (International Organization for Migration) “Dünya Göç Raporu 2020” başlıklı çalış- 
masında yer alan 2019 yılına ait verilere göre, dünya nüfusunun yaklaşık \%3,5'i, yani 272 milyon insan uluslararası göçmen konumundadır (World Migration Report, 2020). Bu durum; kültürlerarası iletişim, toplumların birbirini yakından tanıması, var olan ön yargıların kırılması gibi faydalı durumlar doğursa da oldukça zor durumları da barındırmaktadır. İki farklı kültürün birbirini tanıması sürecinde var olan ön yargılar kırılamayacağı gibi, farklı alanlara ilişkin ön yargılar karşılıklı olarak azaltılabilir. Bu açıdan bakıldığında hedef ülkeye göç eden birey, dezavantajlı konumdadır. Özellikle zorunlu göçe mecbur bırakılan kitleler, sı̆̆ındıkları ülkelerin halkları tarafından birçok olumsuz algıyla karşılaşabilmektedirler. Bu sorunların başında hedef kültüre uyum süreci, eğitim sorunu, dil sorunu, ekonomik ve psikolojik sorunlar mültecilerin baş etmek zorunda kaldığı sorunların sadece birkaçıdır. Bu durum Türkiye'deki Suriyeli mülteciler için de aynı şekilde geçerlidir. "Gittikçe içinden çıkılmayan bir hâl hâline gelen Suriyeli mülteci sorunları artarak devam etmektedir. Özellikle dil, kültür, yaşam tarzı farklılıkları toplumsal uyumu güçleştirmektedir" (Öztürk ve Çoltu, 2018).

Mültecilerin yaşadıkları sorunların çözümüne yönelik alınan tedbirlerin ve geliştirilen projelerin başarıya ulaşmaları için onların hedef kültüre psikolojik ve sosyokültürel açıdan uyum sağlamaları gerekmektedir. Psikolojik uyum, göçmen bireylerin yeni toplumda kendilerini nasıl hissettikleriyle ilgilenirken sosyokültürel uyum ise hedef kültürü benimseme (hedef kültürün dilini öğrenme vb.) ya da etnik kültürü devam ettirip ettirmeme durumu ile ilgilenmektedir (Künüroğlu, 2020). Temelde kendi kültürlerini korumak ve hedef kültüre uyum sağlamak arasında sıkışan göçmen ya da mültecilerin, mevcut arada kalmışlığın getirdiği sorunları aşmak için en iyi yol sığındıkları topluma uyum sağlamaları, yani hedef kültürle bütünleşmeleridir. Bu bütünleşme, en etkili şekilde ancak eğitimle sağlanabilir. Herhangi bir eğitim kurumunda, herhangi bir kademede öğrenci olan bir mülteci çocuk ya da genç, sosyal çevresinde kabul edilen, başarılı bir öğrenci olduğunda hedef kültürü daha çok benimsemeye çalışır. Böylece bireyin, psikolojik ve sosyokültürel uyumu daha kolay ve hızlı bir şekilde sağlanabilir.

Eğitime katılım, mültecilerin sosyo-ekonomik ve psikolojik açıdan hedef kültüre ya da topluma uyumlarını sağlamada bir katalizör işlevi görür. Eğitim, mülteciler açısından daha kıymetli ve mutlaka katılmayı gerektiren önemli bir süreçtir. Çünkü ancak eğitim sayesinde hedef toplumun dili ve kültürü öğrenilebilir, ekonomik hayata ancak eğitimle katılım sağlanabilir. Topraklarına ayak bastığı ülkenin belki de en alt konumunda görülen mülteciler, kendilerine sunulan eğitim imkânlarını, toplumda yer edinebilmek ve toplumsal gereksinimlerini karşılayabilmek için her kademedeki eğitime katılmayı bir fırsat olarak görmektedirler. Yani eğitim, mültecileri hedef toplumda birey hâline getirir, en alt statüde bulunurken süreç sonunda toplumsal açıdan üst basamaklara doğru ilerletir. Birey olarak var olma mücadelesi, uygun ve nitelikli bir eğitim sonucunda gerçekleştirilebilir.

Ülke yönetimlerinin ülkelerine olan ve ön görülen mülteci hareketlerini iyi yönetmesi gerekmektedir. İyi yönetilen göç sürecine bağlı olarak oluşturulan kapsamlı 
göç politikaları, ülkelerin içinde bulundukları durağanlıklarını aşmalarını sağlayarak verimli bir ekonomik alanın oluşmasında önemli bir işlev görür (Dağ, 2020). Mülteci çocukların eğitim sürecine kazandırılması onların gelecekleri ve hedef toplumla uyum sağlamaları açsısından oldukça önemli ve gereklidir. Ancak, eğitimi sadece çocukların ve ergenlerin eğitimi olarak (ilkokul-ortaokul-ortaöğretim) ele almak, sürecin yükseköğretim aşamasının eksik kalmasına neden olabilir. Bu nedenle, özellikle Suriyeli mülteci çocukların eğitime katılımlarının sağlanması ne kadar önemliyse yükseköğretim çağındaki gençlerin de bu sürece dâhil edilmesi o kadar önemlidir.

\section{Suriyeli Mültecilerin Eğitim Sürecine Katılım Durumları}

Suriye iç savaşı ile ortaya çıkan mülteci akınları, son yıllarda yaşanan en büyük insani krizlerin başında gelmektedir. Bu krizden en çok etkilenen ülkenin, Avrupa ve bölge ülkeleri arasında Türkiye olduğu bilinmektedir. Suriyeli mülteciler, ilk yıllarda "misafir" olarak tanımlanmıştır. Yani bu insanların, ülkelerindeki kriz çözüldügünde geri dönecekleri beklentisi hâkimdi. Fakat giderek uzayan iç savaş, Suriye'nin çeşitli devlet ve örgütlerin bir çıkar devşirme sahasına dönüşmesi, "misafir" tanımlamasının "mülteci"ye, son zamanlarda da bu insanların Türk toplumuna "entegrasyon"larının sağlanması gerektiğine dönüşmüştür.

İşgalden kurtarılan bölgeler başta olmak üzere kendi rızalarıyla dönmek istemeyen mültecilerin, toplumun bir parçası hâline gelmeleri ve toplumsal yaşamın her alanına uyum sağlamaları gerekmektedir. Bu kapsamda Türkiye, hem taraf olduğu uluslararası sözleşmelerden de doğan yükümlülüklerinin bir gereği olarak hem de konuya insani açıdan yaklaşarak başta eğitim olmak üzere birçok projeyi ilgili kurumlar aracılığıyla hayata geçirmiştir. Bu proje ve uygulamalarla, okul öncesinden ortaöğretime kadar eğitim çağındaki çocuk ve gençlerin eğitime katılımları sağlanmıştır.

Türkiye'de geçici koruma altında yaşayan Suriyelilerin eğitimleri, kamplardaki geçici eğitim merkezlerinde, kamp dışında ise Millî Eğitim Bakanlığına bağlı devlet okullarında ve özel okullarda yürütülmektedir. Göç idaresi Genel Müdürlüğü verilerine göre, 5-17 yaş aralığındaki eğitim çağı nüfusu her yıl artış göstermektedir. 2020-2021 eğitim-öğretim dönemi itibarıyla bu yaş aralığındaki nüfus, 1.197.124'tür (MEB, 2021). Yıllara göre bu nüfusun eğitime erişim sayıları ve oranları, Grafik 1'de verilmiştir. 
Grafik 1. Yıllara Göre Ülkemizde Eğitime Erişimi Sağlanan Geçici Koruma Altındaki Öğrenci Sayısı

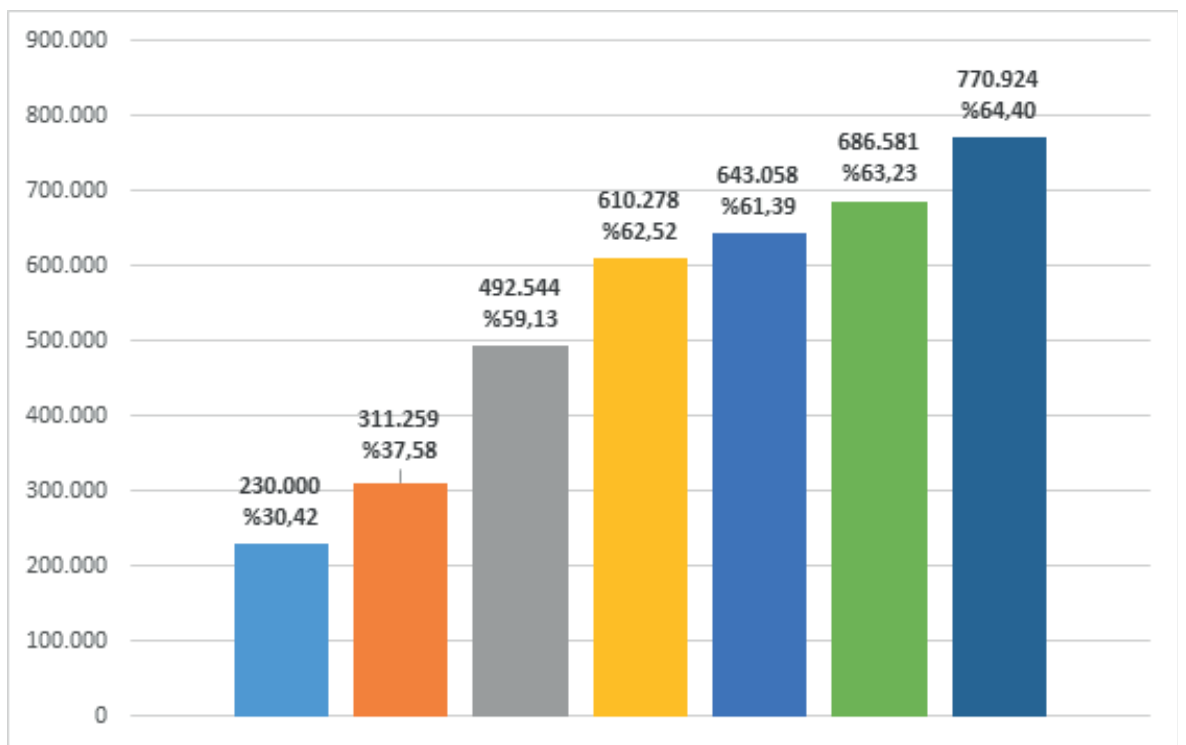

Kaynak: MEB, 2021.

Millî Eğitim Bakanlığının verilerine göre 2014-2015 eğitim-öğretim yılında, ülkemizde eğitime erişimi sağlanan geçici koruma altındaki öğrenci sayısı 230.000; bu sayının okul çağındaki nüfusa oranı \%30,42 iken 2020-2021 eğitim-öğretim yılında öğrenci sayısı, 770.924'e, okul çağındaki nüfusa oranı ise \%64,40'a yükselmiştir. Yani 5-17 yaş aralığındaki Suriyeli nüfusun 2021 yılı itibarıyla \%64,40'ının eğitime erişimi sağlanmıştır. 2014 yılından itibaren uygulanan politikalar sonucunda, geçici koruma altındaki eğitim çağındaki çocukların büyük bir bölümü, eğitim olanaklarından yararlanmaya başlamıştır. Eğitim çağındaki nüfusun eğitim kademelerine göre okullaşma oranları ve sayılarına ilişkin bilgiler, Grafik 2'de verilmiştir. 
Grafik 2. Eğitim Kademelerine Göre Okullaşma

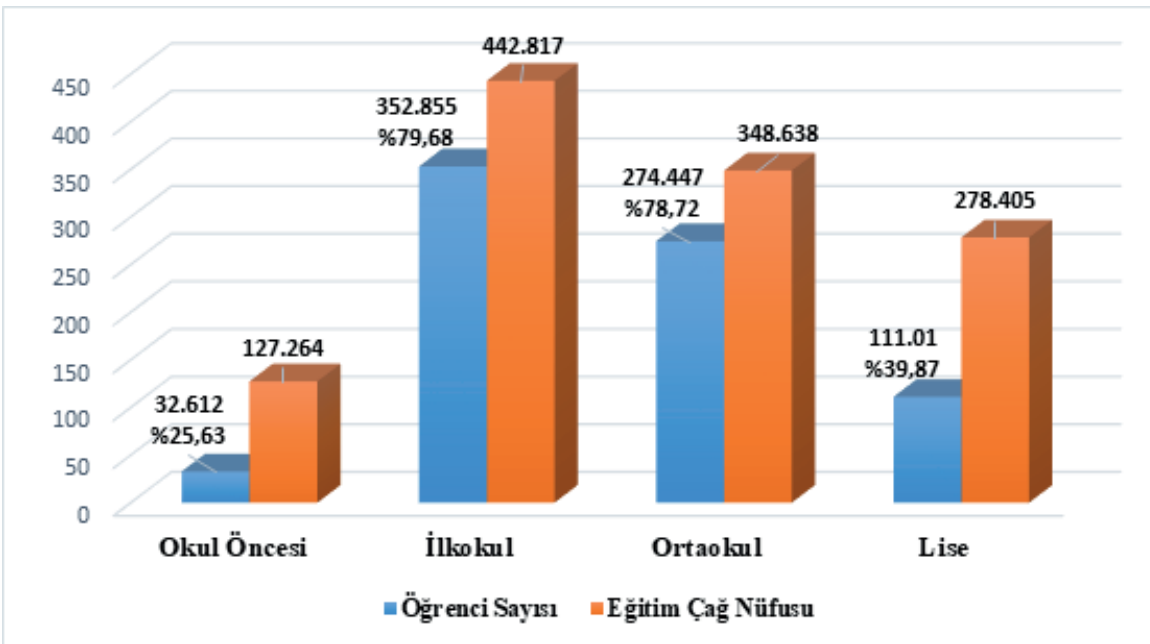

Kaynak: MEB, 2021.

Grafik 2 incelendiğinde geçici koruma altındaki eğitim çağına gelen nüfusun 127.264 'ü okul öncesi çağındaki çocuklardır. 32.612 çocuk $(\% 25,63)$, okul öncesi eğitim kurumlarına gitme olanağı bulmuştur. Eğitim çağındaki toplam nüfus içerisinde ilkokul çağındaki çocukların sayısı, 442.817 ile eğitim kademelerinde en fazla sayıya sahip kademedir. Bu öğrencilerin 352.855'i $(\% 79,68)$ ilkokula kayıtlıdır. Ortaokul çağındaki nüfus 348.638 iken 274.447 'si $(\% 78,72)$ ortaokul kademesinde eğitim hayatlarına devam etmektedir. Lise çağındaki genç nüfusun sayısı 278.405'tir. Ortaöğretim kurumlarına devam eden öğrenci sayısı $111.01(\% 39,87)^{\prime}$ dir. Grafik 2'ye göre, en az okullaşma oranı \%25,63 ile okul öncesi kademesinde, en fazla okullaşma oranı ise \%79,68 ile ilkokul kademesindedir. Lise çağında okullaşma oranında ise ilkokul ve ortaokula göre azalma olduğu görülmektedir.

5-17 yaş aralığındaki eğitim çağına gelmiş Suriyeli mültecilerin okullaşma oranlarının veriler doğrultusunda her geçen yıl arttığ1 görülmektedir. Bu artış, Türkiye'nin uyguladığı mültecilerin topluma uyum kapsamındaki projelerinin somut çıtılarıdır. İlkokul ve ortaokul düzeylerindeki okullaşma oranlarının okul öncesi ve lise kademelerinde de yakalanması gerekmektedir. "Kayıp nesil" oluşmaması ve bu insanların eğitim, ekonomi ve hayatın diğer alanlarına kazandırılması ancak bu şekilde gerçekleştirilebilir. Yükseköğretim çağındaki bireylere, üniversite olanaklarının kazandırılması da ayrıca önem taşımaktadır. 


\section{Suriyeli Genç Nüfusun Yükseköğretim Kurumlarına Katılım Durumları}

18 yaş ve üzeri yetişkin bireylerin yükseköğretime kazandırılması; toplumsal uyum, psikolojik iyi oluş, kabul edilme süreçleri, sosyal dışlanmanın en aza indirilmesi, nitelikli birey hâline gelme gibi pek çok açıdan konunun her iki tarafı için de gereklidir. Yükseköğretim çağındaki Suriyeli mültecilerin akademik hayatlarına devam edebilmeleri için Yurt Dışı Türkler Akraba Topluluklar Başkanlığı (YTB) ile Yükseköğretim Kurulu (YÖK), üniversite çağındaki nüfusun eğitime erişiminde önemli olanaklar sunmuşlardır.

Yükseköğretim Kurulu (YÖK), 3 Eylül 2012 tarihinde yayımladığ1 “Özel Öğrenci" konulu genelge ile 2012-2013 eğitim-öğretim yılına mahsus olmak üzere Suriyeli mültecilere, ülkelerinde yarım kalan üniversite öğrenimlerini sınıra yakın 7 ilde [Gaziantep, Kilis 7 Aralık, Harran (Şanlıurfa), Mustafa Kemal (Hatay), Osmaniye Korkut Ata, Çukurova ve Mersin Üniversitesi], öğrencilik durumlarını gösteren belge ile başvurmaları ya da belgeleri yoksa beyanlarının dikkate alınması yoluyla özel öğrenci olarak ders almalarına olanak tanımıştır. İlgili genelgede 2012-2013 eğitim-öğretim yılı ile sınırlı kalması planlanan bu durum, Suriye'de yaşanan iç savaşın ve insani krizlerin uzun yıllar süreceğinin anlaşılması üzerine, yine Yükseköğretim Kurulunun (YÖK) yatay geçiş işlemlerine ilişkin esaslardaki "EK Madde-2" ile düzenlenmiştir (YÖK, 2021). Buna göre yatay geçiş için istenen belgelere sahip olmayan öğrencilerin yükseköğretim kurumlarından özel öğrenci olarak ders alabilmelerinin önü açılmıştır. Ancak üniversitelerden mezun olabilmek için özel öğrenci olarak asil öğrenci olmak zorunludur. Bu nedenle Suriyeli mülteciler, üniversite öğrenimlerine devam edebilmek için bazı belgeleri ibraz etmek ve birtakım şartlara sahip olmak zorundadırlar.

Yükseköğretim Kurulunun (YÖK) tanıdığı bu imkânın yanı sıra her yabancı uyruklu öğrenci gibi Suriyeli mülteciler de Yabancı Öğrenci Sınavı'na (YÖS) katılarak Türkiye'de bir yükseköğretim kurumunda öğrenim görme hakkına sahiptirler. Önceki yıllarda sınav dili Türkçe ve İngilizce iken Suriye'den ülkemize başlayan göç akınından bağımsız olarak ülkemizin yükseköğretimde bölge ülkeleri Afrika, Rusya, Orta Asya ve Uzak Doğu ülkeleri arasında bir çekim merkezi hâline gelmesi sonucunda, YÖS sınavlarında Arapça, Rusça, Fransızca ve Almanca dilleri kullanılmaya başlanmıştır. YÖS'ün genel olarak uluslararası öğrenciler, özelde de mülteci öğrenciler açısından sinırlılı̆̆ı, her üniversitenin bu sınavı uygulamaması ve üniversitelerin sinavları kabul etme noktasında aralarında birlik olmaması gösterilebilir. Ancak özellikle sınav dilinin çeşitlendirilmesi, başta ülkemizdeki mülteciler olmak üzere dünya genelinde Türkiye'deki üniversitelerde öğrenim görmek isteyenler açısından oldukça önemli bir adimdir.

Yükseköğretim Kurulunun (YÖK) yayımladığı genelgeler ve ilgili yönetmeliklerde yapılan düzenlemelerle Suriyeli mülteci gençler, ülkelerinde bırakmak zorunda kaldıkları akademik hayatlarına Türkiye'de devam etme ya da başlama imkânına ka- 
vuşmuşlardır. Yükseköğretim Kurulunun (YÖK) yanı sıra Yurt Dışı Türkler ve Akraba Topluluklar Başkanlığı, Türkiye Bursları kapsamında dış paydaşlarıyla geliştirdiği burs projelerini hayata geçirmiştir. İlgili kurumda Suriyeli mülteci öğrencilere yönelik 3 farklı burs programı bulunmaktadır. Bu programlar ve ilgili paydaşlar Tablo 2'de verilmiştir.

Tablo 2. Suriyeli Mültecilere Yönelik Burs Programları

\begin{tabular}{|l|c|l|}
\hline \multicolumn{1}{|c|}{ Burs Programının Adı } & Türk Ortaklar & Uluslararası Ortaklar \\
\hline $\begin{array}{l}\text { Suriyeliler İçin Yüksek ve İleri } \\
\text { Öğrenim İmkânları ve Perspektif- } \\
\text { leri (HOPES) }\end{array}$ & HOPES & $\begin{array}{l}\text { BM, DAAD, Nuffic, Campus } \\
\text { France ve British Council. }\end{array}$ \\
\hline $\begin{array}{l}\text { Albert Einstein Alman Akademik } \\
\text { Mülteci Girişimi (DAFI) }\end{array}$ & UNHCR Türkiye & Almanya Dişişleri Bakanlığ1 \\
\hline Birleşmiş Milletler Bursları & UNHCR Türkiye & Birleşmiş Milletler \\
\hline
\end{tabular}

Kaynak: Veriler https://www.turkiyeburslari.gov.tr/tr/sayfa/aday-ogrenciler/burs-programlari adresinden alınarak tablolaştırılmıştır.

Tablo 2 incelendiğinde Suriyeli mülteci öğrencilere sağlanan bursların aslında Avrupa Birliği ülkeleri, Birleşmiş Milletler ve uluslararası faaliyet gösteren çeşitli sivil toplum kuruluşlarının sosyal ve ekonomik katkıları ile verildiği görülmektedir. "Suriye Destek Bursu" adı altında 2015 yılının sonlarında başlatılan programın mali kaynağının \%15'i ulusal, \%85 gibi önemli bir bölümü ise Avrupa Birliği tarafından sağlanmaktadır (YTB, 2021). Burs imkânı, belirlenen şartları sağlayan Suriyeli öğrencilere tahsis edilmektedir. 2020 yılı haziran ayı itibarıyla, 27.606 Suriyeli üniversite öğrencisinin yaklaşık 3.556'sı tam burslu ve yaklaşık 16.000'i ise kısmi burslu olarak öğrenim hayatlarına devam etmektedirler (Hürriyet, 2021).

İlgili kurumların uluslararası destekler ve kurdukları iş birliği sonucunda, 20192020 eğitim-öğretim yılı sonunda üniversitelerde öğrenim gören Suriyeli öğrenci sayısında önemli bir artış yaşanmıştır. Bununla ilgili veriler Grafik 3'te bulunmaktadır. 
Grafik 3. Yükseköğretim Kurumlarına Kayıtlı Suriyeli Öğrenci Sayıları

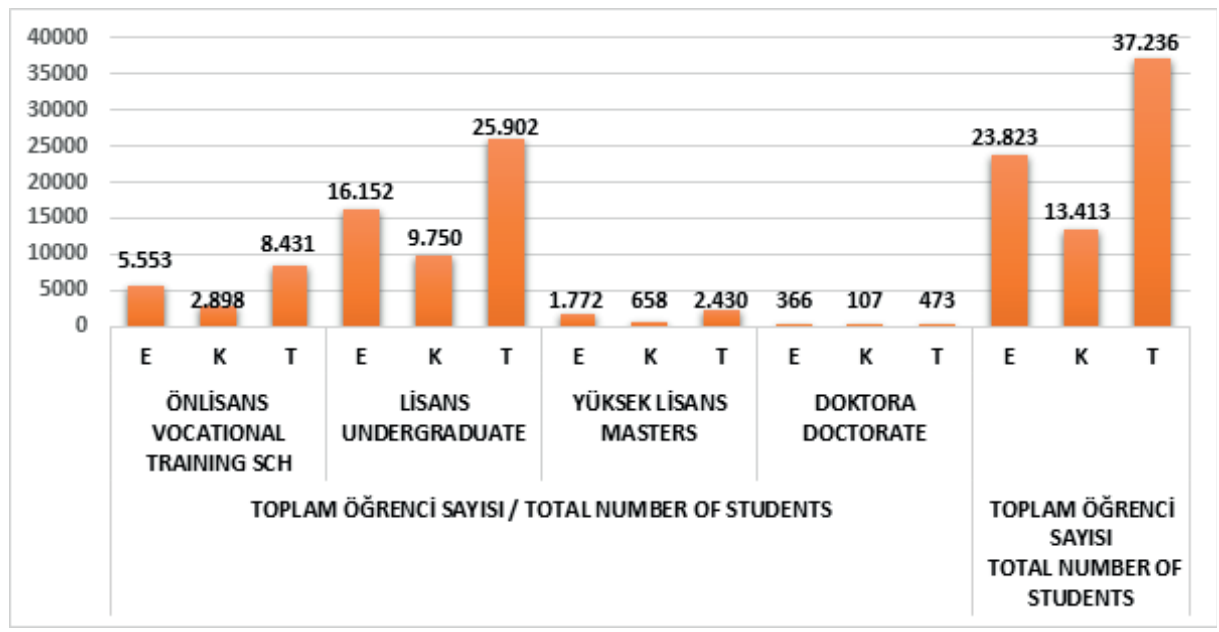

Kaynak: Veriler https:/ /istatistik.yok.gov.tr/ adresinden alınarak hazırlanmıştır.

Yükseköğretim Kurulu (YÖK) verilerine göre 2020 yılı itibarıyla ön lisans, lisans, yüksek lisans ve doktora düzeyindeki Suriyeli mülteci öğrencilerin sayısı toplam 37.236'ya ulaşmıştır. Bu öğrencilerin 15.894'ü, 2019 yılında üniversitelere kayıt yaptıran öğrencilerden oluşmaktadır. En fazla öğrenci sayısı 25.902 ile lisans, en az öğrenci sayısı ise 473 ile doktora düzeyinde gerçekleşmiştir.

Suriyeli mültecilerin Türkiye'deki yükseköğretim kurumlarında öğrenim hayatlarına devam edebilmelerine yönelik yasal düzenlemelerin yapıldı̆̆ı görülmektedir. Ayrıca uluslararası kuruluşlarla yapılan ortak projelerle, diğer uluslararası öğrencilere olduğu gibi belirlenen koşulları taşıyan Suriyeli mültecilere de burs imkânı sağlanmaktadır. Bütün bu girişimler sonucunda, üniversiteye gitmek isteyen veya öğrenim hayatlarına kaldıkları yerden devam etmek isteyen Suriyeli mülteci gençlere bu olanak sağlanmıştır. Böylelikle sayıları artık milyonlarla ifade edilen Suriyeli mülteci gençlerin önemli bir bölümünün "kayıp nesil" olmaktan kurtarıldığını söylemek mümkündür.

\section{Suriyeli Üniversite Öğrencilerinin Karşılaştıkları Sorunlar}

Suriyeli mültecilerin eğitim çağındaki genç nüfusun eğitime erişim/okullaşma oranları; onların topluma uyumlarının sağlanması, nitelikli bireyler olarak yetişmeleri ve iş gücüne katılımları gibi birçok açıdan büyük önem taşımaktadır. Yükseköğretim çağındaki Suriyeli gençlerin, ilk yıllarda yaşadıkları eğitim kurumlarına erişememe sorunu, ulusal ve uluslararası sivil toplum kuruluşları ile devlet kurumlarının bu sorunu 
ortadan kaldırmaya yönelik geliştirdikleri politikalar ve uygulanan projeler ile büyük ölçüde giderilmiştir. Bu durum, YÖK'ün istatistiklerine de yansımıştır (bkz. Grafik 3). 10 yıl içerisinde yükseköğretime katılan Suriyeli öğrenci sayısında önemli bir artış olsa da yaşanılan sorunlar tamamen çözülememiştir. Bu sorunların başında, öğrencilerin sosyal ve akademik hayatlarını doğrudan etkileyen dil sorunu gelmektedir.

Suriye iç savaşının ardından gerçekleşen kitlesel göç akınları ve ülkemize sığınan Suriyeli mültecilerin uzun bir süre, belki de hiçbir zaman ülkelerine dön(e)meyeceklerinin anlaşılması, mülteci krizinin doğurduğu birçok soruna kalıcı çözüm üretilmesini zorunlu hâle getirmiştir. Bu sorunlardan birisi belki de en önemlisi, mültecilere Türkçe öğretimi sorunudur. Suriyeli mültecilere çeşitli kurumlar tarafından birçok kademede ve farklı yaş gruplarında Türkçe öğretimi verilmektedir. Türkçe öğretimi yapılan kurumlar Şekil 1'de verilmiştir (Coşkun ve Emin, 2016).

Şekil 1. Suriyelilere Türkçe Öğreten Kurumlar

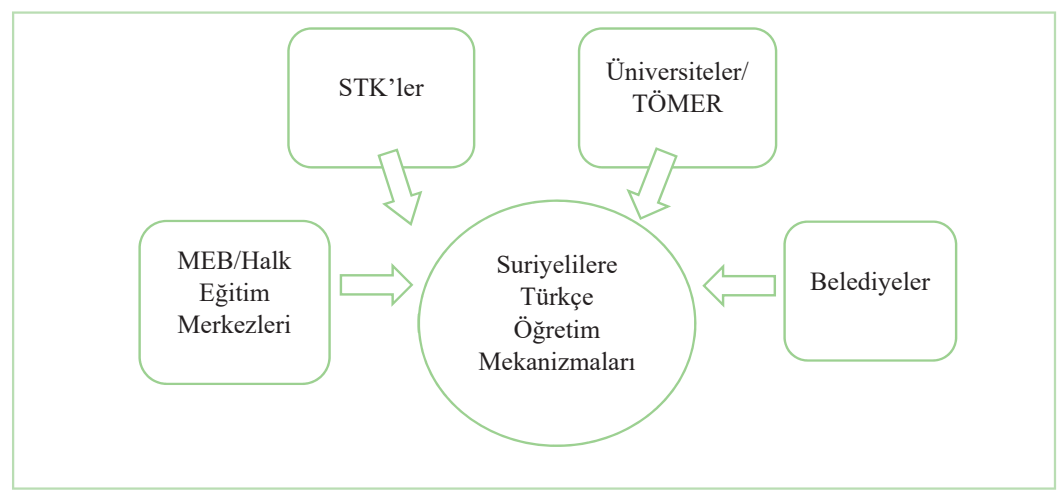

Kaynak: http:/ / file.setav.org/Files/Pdf/20160906135243_turkiyedeki-suriyelilerin-egitiminde-yol-haritasi-pdf.pdf

Şekil 1 incelendiğinde Suriyeli mültecilere yönelik birçok kamu kurumunun ve STK'lerin Türkçe öğretimine yönelik faaliyetlerinin olduğu görülmektedir. Bütün uluslararası öğrencilerin üniversite öğrenimlerine devam edebilmeleri için katılmaları gereken Türkçe öğretimi kursları, üniversiteler bünyesinde bulunan Türkçe Öğrenim Uygulama ve Araştırma (TÖMER) merkezlerince verilen Türkçe kurslarıdır. Bu kurumlarda verilen Türkçe öğretimi, temel düzeyden (A1-A2) başlayarak ileri seviyelere (C1) kadar devam etmektedir. Üniversitelerin birçoğu, uluslararası öğrencilerin lisans ve lisansüstü öğrenimlerine başlayabilmeleri için C1 düzeyinde Türkçe sertifikasını şart koşmaktadır. Ancak bazı üniversiteler ve bölümler, B2 sertifikasını da yeterli bulmaktadırlar. Bu durum yurtdışından Türkiye'ye gelerek akademik hayatlarına devam etmek isteyenler için olduğu gibi Suriyeli mülteciler için de geçerlidir. Bu noktada TÖMER'lerde verilen Türkçe öğretiminin niteliği tartışmalı bir konu olmakla birlikte birçok kişinin geleceği açısından önem taşımaktadır. 
Üniversitelerde akademik düzeyde Türkçeyi yabancı dil olarak öğreten birimler TÖMER'lerdir. Türkçenin yabancı dil olarak öğretimi alanındaki birçok sorun, mültecilere Türkçe ögrretimini de etkilemektedir. İlgili alanda henüz bir akreditasyon kuruluşu bulunmamaktadır. Yani özel veya resmî, yabancılara Türkçe öğretmek amacıyla kurulacak olan yerlerin, hangi ölçütlere sahip olması gerektiğini belirleyen bir kurum henüz yoktur. Bu durum her bir TÖMER'in kendi programını, kendi öğretim aracını, kendi ölçme-değerlendirme sürecini oluşturmasına neden olmaktadır. Bu nedenle TÖMER'lerden C1 Türkçe yeterliğine sahip olduğunu gösteren belgeyi alan öğrenciler, fakülteye geçtiklerinde çok büyük sorunlarla karşı karşıya kalmaktadırlar. Ayrıca günlük iletişim, sosyalleşememe, uyum sorunlarının da en önemli kaynağı dil sorunudur. Esasında dil sorunu çift yönlüdür. Suriyeli mültecilerin Türkçe bilmemesi, Türklerin de İngilizce veya Arapça iletişim becerilerinin olmaması, ülkeye ilk gelişte uyum sorunlarının yaşanmasının ve bu sorunların uzun süre devam etmesinin başlıca nedenlerindendir.

Yapılan araştırmalar (Coşkun ve Emin, 2016; Yıldız, 2019; Şahin ve Çelik, 2020), yükseköğretim aşamasındaki Suriyeli mülteci öğrencilerin en fazla yaşadıkları sorunun dil sorunu olduğunu ortaya koymaktadır. Bu sorun birçok sorunun da kaynağıdır. Örneğin sosyal dişlanma, psikolojik ve sosyal uyum sorunları, akademik başarısızlık, resmî kurumlarda iletişim kuramama gibi hayatı ve geleceği doğrudan etkileyen birçok sorun, dili yeterince öğretememe ve dil becerilerinin yeterli düzeyde edindirilememesinden kaynaklanmaktadır. TÖMER'deki Türkçe kurslarını başarıyla tamamlasalar bile öğrencilerin özellikle konuşma ve yazma becerilerinde desteğe ihtiyaç duydukları bilinmektedir (Yıldız, 2019). Öğretim sürecinin niteliği kadar Türkçeyi yabancı dil olarak öğretenlerin alan yeterlikleri ve bilgileri de tartışmalıdır. Birkaç haftalık sertifika programları ile yabancı dil öğreticisi yetiştirilmesi mümkün değildir. Bir yıl boyunca Türkçe öğrenen bir insanın akademik hayatında çok başarısız olması, yabancılara Türkçe öğretimi alanında birçok uygulamanın gözden geçirilmesinin zamanının geldiğini göstermektedir.

\section{Sonuç ve Öneriler}

Mültecilerin toplumsal hayata kazandırılması, nitelikli iş gücüne ve eğitime sahip insanların keşfedilmesi, karşılıklı faydayı beraberinde getirecektir. Türkiye'ye göç etmek zorunda kalan milyonlarca Suriyeli ile Türkiye, daha önce üzerinde durulmayan birçok sosyal, ekonomik, psikolojik vb. alanlarda farklı sorunlarla karşı karşıya kalmıştır. Bu sorunların çözülmesi için hızla harekete geçen ilgili devlet kurumları ve sivil toplum kuruluşları birçok proje geliştirmiştir. Böylece Suriyeli mültecilerin Türk toplum hayatına uyumları hızlandırılmış, eğitimin her kademesinde yer bulmaları sağlanmıştır.

Eğitim çağındaki Suriyeli mültecilerin, okul öncesinden yükseköğretime kadar okullaşmaları ve başarılı olmaları yaşanan birçok sorunun da çözümünü sağlayacaktır. Özellikle üniversite çağındaki genç nüfusun nitelikli bireyler olarak yetişmeleri, 
kendi açılarından faydalı olacağı gibi Türk toplumunun mültecilere bakış açısının değişmesini de sağlayacaktır. "Türkiye'de kalmayı düşünen Suriyeli üniversite öğrencileri aldıkları üniversite eğitimi doğrultusunda meslek edinmeyi amaçlamakta ayrıca gerekli şartları sağladıkları takdirde Türk vatandaşlığına geçmeyi düşünmektedirler. Bazı öğrenciler Türkiye'de kendi alanlarıyla ilgili akademik hayata yönelik planlar da yapmaktadırlar" (Harunoğulları, Süzülmüş ve Polat, 2019).

Yükseköğretim kurumlarındaki Suriyeli mülteci öğrenci sayısı, Suriyeli toplam genç nüfusa oranlandığında oldukça düşük bir oranı işaret etmektedir. Bu durumun ortaya çıkmasında, üniversiteye kabul edilmeleri için belli şartlara sahip olmaları ve ekonomik nedenlerden dolayı çalışmayı tercih etmelerinin etkili olduğu düşünülmektedir. Bunun yanı sıra, dil kursuna gitmiş olsa dahi Türkçesinin yetersiz olduğunu düşünüp okulu bırakanlar ya da başlamaya cesaret edemeyenler de bulunmaktadır. Bu noktada, gerek toplumsal uyum ve birçok sorunun çözümünde gerek akademik hayatın devamlılığ1/başarısı için nitelikli bir Türkçe öğretiminin gerekliliği görülmektedir. Geçici Eğitim Merkezleri (GEM), Halk Eğitim Merkezleri (HEM) ve TÖMER'ler bünyesinde açılan Türkçe kurslarının süreç-sonuç açısından bütün bileşenleriyle ele alınması gerekmektedir.

2011 y1lından bu yana belki de binlerce Suriyeli mülteci öğrenci TÖMER'lerde Türkçe kurslarına katılmıştır. Ancak Yükseköğretim Kurulu ve üniversiteler arasında öğrenci sayılarının, öğrencilerin akademik başarılarının ve diğer konulara doğrudan ulaşılabilecek bir veri tabanının olmaması, durumun tarafsız bir şekilde analiz edilmesini güçleştirmektedir. Bu nedenle özellikle akademik amaçlarla Türkçe öğrenen Suriyeli mülteci ögrencilerin takibi oldukça güçtür. Öğretimde, ders araç-gereçlerinde ve ölçme-değerlendirme süreçlerinin dağınıklıklarının giderilmesi ve yalnızca Suriyeli mültecilerin değil, diğer uluslararası öğrencilerin akademik durumlarının takibi açısından bu istatistiklerin üniversiteler tarafından kayıt altına alınıp Yükseköğretim Kuruluna bildirilmesi araştırmacılara ve politika yapıcılara yol gösterici olacaktır.

TÖMER'lerde ve diğer kurumlarda Türkçe öğrenenlerin, akademik ve sosyal hayatlarında yaşadıkları sorunların en aza indirilmesi için Türkçenin yabancı dil olarak öğretimi alanında yetişmiş öğreticilerin istihdamı öncelenmelidir. Çok kültürlü, çok dilli sınıflarda öğretim yapacakların sahip olması gereken birçok özellik bulunmaktadır. Bu bağlamda,

- Üniversitelerin Eğitim Fakülteleri bünyesinde ilgili alana yönelik bölümler kurulmalıdır. Bu bölümler, sınırlı sayıda öğrenci alarak mezunlarının mülteci öğrencilerin öğrenim gördüğü okullarda istihdam edilmeleri gerekmektedir. Çünkü Türkçe öğretimi yalnızca yabancılara değil, yurt dişındaki Türk çocuklarına, mültecilere/göçmenlere ve diğer birçok gruba öğretilmektedir. Türkçe öğretmenliğinin lisans programinda yer alan, bir dönemde iki saat verilen Yabancılara Türkçe Öğretimi dersi, alana yönelik öğretmen ihtiyacına cevap vermekten oldukça uzaktır. İlgili bölümün lisans programına iki dillilik, mültecilere/göçmenlere Türkçe öğretimi gibi dersler de eklenmelidir. 
- Türkçe öğretmenlerinin yetiştirilmesinde, Yunus Emre Enstitüsü ve TÖMER'lerden destek alınmalıdır. Hâlihazırda görev yapmakta olan öğreticiler, içeriği iyi belirlenmiş bir hizmet içi eğitime tâbi tutulmalıdır. Bu eğitimler, alanında uzman akademisyenler ve sahanın içinden gelen uygulayıcılar tarafından verilmelidir. Süreç sonunda da tarafsız ve uygun bir ölçme ile bu hizmet içi eğitimlerin işe yararlığı belirlenmelidir. Böylece sonraki kurslar daha iyi duruma getirilebilir.

- TÖMER'lerde yapılan Türkçe öğretiminin niteliği; öğretici, materyal, öğretim programı, ölçme-değerlendirme açısından geliştirilerek dilden kaynaklı sorunlar en aza indirilebilir. Bunun için YÖK ya da YTB bünyesinde, uluslararası öğrencilere yönelik bir birim ihdas edilerek ya da var olan ilgili birimler tarafından, TÖMER'lerde yapılan Türkçe öğretiminin standartları, ilgili paydaşların da görüşleri alınarak belirlenmelidir. Böylece öğretim açısından birlik sağlanmalıdır.

- YTB her yıl binlerce uluslararası öğrenciye burs sağlamaktadır. Türkçe öğretimi açısından benzer sorunlar, bu öğrenciler için de geçerlidir. Özellikle ölçme-değerlendirme açısından TÖMER sınavları birbirinden oldukça farklıdır. Bir kurumun yaptığ sınavdan C1 sertifikası alan bir öğrenci başka bir kurumun sınavından daha alt seviyelerde sertifika alabilmektedir. Bu durum öğretimde de ölçme-değerlendirme açısından da büyük sorunlar olduğunu göstermektedir. Bunun çözümüne yönelik adımların ivedilikle atılıp uygulamaların hayata geçirilmesi gerekmektedir.

- Sivil toplum kuruluşları bu konuda daha fazla sorumluluk üstlenmelidir. Suriyeli mültecilerin yükseköğretimde karşılaştıkları sorunların en aza indirilmesi için devlet kurumları ile ortak hareket edilmelidir.

10. yılını dolduran Suriye iç savaşından kaçarak ülkemize sı̆̆ınan Suriyelilerin Türkçe öğretim süreçlerine ve yeterliklerine ilişkin birçok araştırma yapılmış ve çeşitli kuruluşlar tarafından raporlar hazırlanmıştır (Büyükikiz ve Çangal, 2016; Coşkun ve Emin, 2016; Emin, 2016; Özarslan, 2018; Ayvazoğlu ve Kunuroğlu, 2019; Gaziantep Üniversitesi 2019; Anis, 2019; Kiremit, 2019; Açıkel, 2019; Yıldız, 2019; Erdoğan, 2020). Bu çalışmalara farklı disiplinlerde yapılmış birçok çalışma eklenebilir. İlgili alanyazın incelendiğinde Suriyeli mültecilere ilişkin yapılan çalışmaların büyük çoğunluğunun toplumsal uyum, mülteci çocuklar, ilkokul, ortaokul ve ortaöğretimde eğitim gören nüfusa yönelik olduğu görülmektedir. Suriyeli mülteci gençlerin yükseköğretime kazandırılması, eğitim süreci ve süreç sonrasını inceleyen çalışmalar ise oldukça sınırl1dır. Yükseköğretimde başarının sağlanmasında, özellikle genç nüfusun bulundukları ülkeye uyum sağlamaları ve yeni bir hayat kurabilmeleri açısından kuramsal ve deneysel çalışmaların faydalı olacağı düşünülmektedir.

Cumhurbaşkanlığı tarafından "Yunus Emre ve Türkçe Yılı" ilan edilen 2021 yılı, Türkçe öğretiminin her anlamda ilgili paydaşlarla niteliğinin artırılmasına yönelik yol haritalarının belirlenmesi, ilgili kurumların güçlendirilmesi, dilimizin "Dünya Dili" olması yolunda önemli bir fırsattır. 
Türk Yükseköğretiminde Suriyeli Mülteciler

\section{Kaynakça}

Açıkel, N. (2019). İstanbul'daki Suriyeli üniversite gençliği üzerine nitel bir araştırma [Yayımlanmamış Yüksek Lisans Tezi]. İstanbul Üniversitesi, Sosyal Bilimler Enstitüsü, İstanbul.

Akar Yüksel, B. \& Bingöl,Y. (2013). The Arab spring in Tunusia: A liberal democratic transition? Elektronik Sosyal Bilimler Dergisi, 12(47), 310-327.

Anis, R. (2019). Devlet ilkokullarında eğitim gören Suriyeli öğrencilerin akademik başarılarını etkileyen faktörlerin incelenmesi [Yayımlanmamış Yüksek Lisans Tezi]. Gaziantep Üniversitesi, Eğitim Bilimleri Enstitüsü, Gaziantep.

Ansarian, M. (2020). Arap Baharı'nın ekonomik etkileri. Niğgde Ömer Halisdemir Üniversitesi Sosyal Bilimler Enstitüsü Dergisi. 2(1), 43-51.

Aydoğdu, Ü. R., Karamustafaoğlu, Orhan ve Bülbül, M. Ş. (2017). Akademik araştırmalarda araştırma yöntemleri ile örneklem ilişkisi: doğrulayıcı doküman analizi örneği. Dicle Üniversitesi Ziya Gökalp Eğitim Fakültesi Dergisi, 30, 556-565.

Ayvazoğlu Şafak, A. ve Künüroğlu, F. (2019). Being a Syrian university student in Turkey: intergroup relations, psychosocial issues, and boundary formation. Refugee Survey Quarterly, 38, 425-447.

Battır, O. (2020). Dünden bugüne uluslararası göç-kuram, algı ve siyasa. Nobel Bilimsel Eserler.

Büyükikiz, Kadir K. ve Çangal, Ö. (2016). Suriyeli misafir öğrencilere Türkçe öğretimi projesi üzerine bir değerlendirme. Uluslararası Türkçe Edebiyat Kültür Eğitim Dergisi, 5(3), 1414-1430.

Coşkun, İ., Emin, Nur M. (2016). Türkiye'deki Suriyelilerin eğitiminde yol haritast: firsatlar ve zorluklar. SETA Yayınları.

Dağ, A. (2020). Göç ve Eğitim, T. Y. Kardeş, F. A. Gök, A. S. Serpen (Eds.), Göç: Sosyal ve Ekonomik Incelemeler, içinde (s. 141-158). Ankara: Nobel Bilimsel Eserler.

Efe, I., Pandır, M., Paksoy, F. Alaaddin (2018). Algılar ve gerçekler arasında Türk basınında Suriyeli sığınmacılar. Nobel Bilimsel Eserler.

Emin, Nur M. (2016). Türkiye'deki Suriyeli çocukların eğitimi: temel eğitim politikaları. SETA Yayınları.

Erdoğan, Z. (2020). Birleşik Krallık'ta mülteci entegrasyon politikaları ve ulusaşırı bağların rolü: yükseköğretimde Suriyeliler (Yayımlanmamış Doktora Tezi). Ankara Yıldırım Beyazıt Üniversitesi, Sosyal Bilimler Enstitüsü, Ankara.

Gaziantep Üniversitesi Göç Enstitüsü (2019). Suriyeli öğrencilerin yükseköğretime entegrasyonu proje raporu. Gaziantep Üniversitesi Yayınları.

GIGM (2020). “Geçici Koruma”. https:/ /www.goc.gov.tr/gecici-koruma5638

Harunoğulları, M., Süzülmüş, S. ve Polat, Y. (2019). Türkiye'deki Suriyeli üniversite öğrencileri ile ilgili bir durum tespiti: Osmaniye Korkut Ata Üniversitesi örneği. Afyon Kocatepe Üniversitesi Sosyal Bilimler Dergisi, 21(3), 816-837. 


\section{MíLLî EĞITiM • Cilt: 50 • Özel Sayı/2021 • Sayı: 1, (1245-1264)}

Hürriyet. (2021). Üniversitelerde 27 binden fazla Suriyeli öğrenci var. https://www.hurriyet. com.tr/egitim/universitelerde-27-binden-fazla-suriyeli-ogrenci-var-41550989 (Erişim tarihi: 02.02.2021)

IOM (2020). "World Migration Report". https://publications.iom.int/system/files/pdf/ wmr_2020.pdf

IOM (2020). World migration report. International Organization for Migration.

Karaçam, Z. (2013). Sistematik derleme metodolojisi: sistematik derleme hazırlamak için bir rehber. Dokuz Eylül Üniversitesi Hemşirelik Yüksekokulu Elektronik Dergisi, 6(1), 26-33.

Kiremit, Rahime F. (2019). Geçici koruma altındaki 3-5 yaş grubu Suriyeli çocukların CLIL yöntemine dayalı verilen Türkçe eğitiminin alıcı dil gelişimlerine etkisi [Yayımlanmamış Doktora Tezi]. Gazi Üniversitesi, Eğitim Bilimleri Enstitüsü, Ankara.

Künüroğlu, F. (2020). Göç, Kültürleşme Süreçleri ve Psiko-Sosyal Uyum, A. Doğan, D. Y. Kağn1c1 (Eds.), Göçmen, Çocuk ve Ergeneler-Kültürleşme, Uyum ve Eğitim içinde (s. 1-25). Nobel Yayıncilik.

MEB(2021).https://hbogm.meb.gov.tr/meb_iys_dosyalar/2021_02/23104924_ocak_2021__ynternet_bulteny_Sunu.pdf (Erişim tarihi: 30.01.2021).

Nebati, N. (2019). Ortadoğu'da demokrasiyi geliştirme hareketi olarak Arap Baharı. The Turkish Online Journal of Design, Art and Communication - TOJDAC, 9(2), 178-190.

Özarslan, A. (2018). Türkçeyi yabancı dil olarak öğrenen Suriyelilerin yazma becerileri üzerine bir araştırma [Yayımlanmamış Doktora Tezi]. İnönü Üniversitesi, Eğitim Bilimleri Enstitüsü, Malatya.

Öztürk, S. ve Çoltu, S. (2018). Suriyeli mültecilerin Türkiye ekonomisine etkileri. Balkan Sosyal Bilimler Dergisi, 7(13), 188-198.

Paksoy, S. (2017). Suriyeli sığınmacıların Kilis ekonomisine etkisi. ASSAM Uluslararası Hakemli Dergi, 4(9), 56-79.

Sayın, Y. (2019). Arap Baharı ve Tunus'un Yasemin Devrimi'ni yeniden anlamak. International Journal of Politics and Security, 1(2), 104-121.

Soguk, N. (1999). States and strangers: Refugees and displacements of statecraft. Minneapolis: University of Minnesota Press.

Şahin, Sümeyye A. ve Çelik, Z. (2020). Dışlanma ve umut arasında: Suriyeli yükseköğretim öğrencilerinin deneyimleri. Yükseköğretim ve Bilim Dergisi, 10(3), 494-503.

Tuygan, A. (2011). Arap Baharı ve Libya örneği. Mülkiye, XXXV(272), 151-162.

UNHCR (2018). Suriye Acil Durumu. https://www.unhcr.org/tr/suriye-acil-durumu

YTB (2021). Suriyeli Öğrenciler İçin Destek Bursları. https://wwww.ytb.gov.tr/duyurular/suriyeli-ogrenciler-icin-destek-burslari-2 (Erişim tarihi: 25.01.2021). 
Türk Yükseköğretiminde Suriyeli Mülteciler

Yıldız, A. (2019). Suriye uyruklu öğrencilerin Türkiye'de yükseköğretime katılımları. Yaşar Üniversitesi Yayınları.

Yılmaz, F. M. (2020). Arap baharının Türkiye ile Ortadoğu devletleri arasındaki ekonomik ilişkilere etkisi. Ahi Evran Akademi Sosyal Bilimler Dergisi, 1(1), 10-36.

YÖK, (2021). Ek madde-2 uyarınca mısır ve Suriye'den yapılabilecek yatay geçiş işlemlerine ilişkin esaslar. https://www.yok.gov.tr/ogrenci/ek-madde-2-uyarinca-misir-ve-suriyeden-yapilabilecek-yatay-gecis-islemlerine-iliskin-esaslar (Erişim tarihi: 2.02.2021). 